\title{
Seasonal Activity, Natural Enemies and Life Table Parameters of Cryptoblabes gnidiella Mill. on Mango Inflorescences Abdel Kareim, A. I. ${ }^{1}$; M. E. Ragab ${ }^{1}$; N. M. Ghanim² and Samira A. Abd El-Salam² ${ }^{1}$ Faculty of Agric., Mansoura Univ. \\ ${ }^{2}$ Plant Protection Research Institute, Dokki, Giza, Egypt.
}

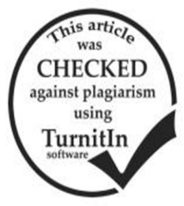

\section{ABSTRACT}

The population density of the honeydew moth (HM), Cryptoblabes gnidiella Mill. (Lepidoptera: Pyralidae) and its associated natural enemies was estimated in neglected (without chemical control treatments) orchard cultivated with mango trees (Mangifera indica L.), located at Shirben district, Dakahlia governorate, Egypt. The obtained results showed that this pest was recorded only at the height of $2.5 \pm 0.5$ meters and was not at the height of $5.5 \pm 0.5$ meters from the ground. The population of $C$. gnidiella had three peaks of abundance annually. During the two seasons of study, the anthocorid predator, Orius sp. was mainly associated with C. gnidiella population. In addition, an endo-parasitoid species was firstly observed on $C$. gnidiella larvae, namely, Tachina larvarum (Order: Diptera, Family: Tachinidae). Orius sp. exhibited three peaks of seasonal abundance annually. The total number of collected predator showed high significantly positive correlation with the average population density of the prey in the first and second years $(\mathrm{r}=0.51 * *$ and $0.63 * *)$. The population of $T$. larvarum exhibited four peaks of abundance annually. The percentage of parasitism all over the season averaged $13.2 \pm 3.2$ and $14.3 \pm 5.01 \%$ during 2016 and 2017, respectively. Statistical analysis indicated that there were significant positive correlations between populations of $C$. gnidiella and its parasitoid during the first $\left(\mathrm{r}=0.65^{* *}\right)$ and second $\left(\mathrm{r}=0.79^{* *}\right)$ seasons. Life and fertility tables of $C$. gnidiella reared on mango inflorescences were conducted under laboratory conditions. The developmental time of the egg, larvae and pupal stages lasted $4.1 \pm 1.8,14.4 \pm 0.6$ and $10.7 \pm 0.9$ days respectively. The generation time, the net reproductive rate $\left(\mathrm{R}_{\mathrm{O}}\right)$ and intrinsic rate of increase $\left(\mathrm{r}_{\mathrm{m}}\right)$ were 35.97 days, $29.03 \mathrm{females} / \mathrm{female}$ and $0.04 \mathrm{female} / \mathrm{female} /$ generation.

\section{INTRODUCTION}

The honeydew moth (HM), Cryptoblabes gnidiella Mill. is an opportunistic species native to the Mediterranean region (Dawidowicz \& Rozwalka, 2016). Nowadays, C. gnidiella is recorded all over the world, attacking several hosts mainly pomegranate, grapes, citrus, avocado, figs, mangoes, mulberry, as well as several field and vegetable crops (Ben Yehuda et al., 1991; Hashem et al., 1997 and Dawidowicz \& Rozwalka, 2016). It is considered a serious pest together with accompanying insects such as mealybugs. Bagnoli and Lucchi (2001) stated that larval diet includes sweet matter, dry flower parts, berry juice, berry stalk, and even healthy grapes. Larval populations can be very high, especially if they are close to a large colony of mealybugs. Harari et al. (2007) mentioned that damage caused by $C$. gnidiella is twofold, direct damage "caused to clusters when the larvae feed among the berries" and indirect damage "characterized by fungal infestation of injured berries". Wysoki et al. (1993) reported that HM caused losses reached 30\%.

Chemical control is costly, adversely affect the natural enemies, and pollute the environment. In Brazil, Bisotto-de-Oliveira et al. (2007) reported that $C$. gnidiella, is an important pest on grapevine orchards, five parasitoid species of Hymenoptera were found associated with $C$. gnidiella, and parasitoid populations were observed with high abundance in the orchard without application of insecticides. Hashim et al. (2017) recommended that control of $C$. gnidiella could be effectively achieved by the safe means. Little attention has been directed towards predatory insects that are believed to make an important contribution to the mortality of lepidopterous species (Bugg and Wilson, 1989; Mansour, 2004; EL-Barbary, 2006 and Abd El-Kareim et al., 2008).

Efficient control of economic insects requires detailed investigations of the ecology and biology of these insects as well as the natural enemies were recorded as biocontrol agents against lepidopterous insects as HM population. Some criteria are essential for the control of $C$. gnidiella such as adult population dynamics, peak times of population and generation number (Öztürk and Ulusoy,
2012). Therefore, the present investigation deals with some ecological and biological aspects of the honeydew moth under field and laboratory conditions.

\section{MATERIALS AND METHODS}

\section{Estimation the population density of the honeydew} moth (HM), Cryptoblabes gnidiella Mill. and its natural enemies:

\section{Experimental orchards:}

The experiments were conducted in a neglected (without chemical control treatments) orchard of about 2 feddans (a feddan $=4200 \mathrm{~m}^{2}$ ) cultivated with mango trees (Mangifera indica L.), located at Shirben district, Dakahlia governorate, Egypt.

\section{Sampling procedure:}

To estimate the population density of $C$. gnidiella and its associated natural enemies, five homogenous mango trees (in size and age) were randomly chosen. Samples were started from the $8^{\text {th }}$ of February (in 2016 and 2017 ) and continued till the $24^{\text {th }}$ and $25^{\text {th }}$ of October (2016 and 2017). Samples were weekly collected at two height levels ( $2.5 \pm 0.5$ and $5.0 \pm 0.5$ meters) above the ground from the trees. Each sample consisted of 20 inflorescences/level (4 inflorescences/tree) that collected from different sides (north, south, east and west) of the tree. The collected samples were kept in paper bags and then they were pulled up and taken to the laboratory for inspection by using a binocular microscope. Number of HM larvae and pupae were counted and recorded.

The collected $C$. gnidiella larvae and pupae of each sample were maintained in Petri-dishes $(10 \mathrm{~cm}$ in diameter) containing pieces of moistened cotton wools till emergence of the parasitoids. The emerged parasitoids were counted, recorded and identified in Plant Protection Research Institute, Agricultural Research Center. The average percentages of parasitism were calculated during the two successive years (2016 and 2017). The predators in the collected samples were also counted and recorded.

3. Statistical analysis:

The obtained data were statistically analysed using the computer program of CoHort Software (2004), where 
correlation and regression analysis were done. In addition, Duncan's Multiple Range Test was also done by using one way ANOVA to estimate the Least Significant Difference (LSD) with the same computer program.

\section{Life and fertility tables:}

Life and fertility table parameters of $C$. gnidiella were evaluated on floral clusters of mango under laboratory conditions $\left(26 \pm 2^{\circ} \mathrm{C}\right.$ and $\left.65 \pm 5 \% \mathrm{RH}\right)$.

\section{Rearing technique:}

The HM individuals were obtained as pupal stage from the Experimental orchard. These pupae were collected in late June. Pairs of male and female pupae were deposited in $9 \mathrm{~cm}$ diameter Petri-dishes, with a piece of moistened cotton wool on a filter paper in the dish bottom, and kept until emergence.

To have an initial population of HM eggs homogenous in age, newly emerged adults were collected from the stock culture and caged in transparent plastic boxes $(15 \times 20 \times 10 \mathrm{~cm})$. Each box was provided with a piece of moistened cotton wool soaked in a $10 \%$ honey solution as a source of food for the moths, in addition, flowers of mango inflorescences for oviposition. The eggs laid on the inflorescences were daily removed with a soft camel hair brush and placed in clean Petri-dishes. The flowers daily were replaced and honey solution was also changed.

\section{Life and fertility tables for Cryptoblabes gnidiella:}

An initial population of 150 newly deposited eggs (collected from the stock culture) was placed in other three transparent plastic boxes. When the eggs developed to the larval stage, the resulting larvae were daily provided with fresh flowers of mango infested with the mealybug, Planococcus citri until pupation. The daily numbers of dead individuals of each stage were recorded and the duration of each stage was calculated. The number of emerged adults were sexed and counted.

To study the fecundity table, newly emerged twenty pairs of moths were caged in glass jars; each pair in a cage containing mango inflorescences for oviposition. The daily number of eggs laid per female was recorded. The experiment was conducted during June (2017) in the laboratory where the average temperature and relative humidity were daily recorded. Each glass jar was provided with a piece of moistened cotton wool soaked in a $10 \%$ honey solution as a source of food for the moths. The old flowers were daily replaced and honey solution was also changed for each pair of moths.

Age-specific survival table constructed with the following columns:

$\mathrm{X}$ : The pivotal age for the age class in days.

$l_{x}$ : The number of surviving at the beginning of age class $x$. $d_{x}$ : The number of dying during the age interval $x$. $q_{x}$ : The mortality rate per age interval as the rate per thousand. Age-specific fertility table constructed with the following:

$X$ : Actual female age (time from egg stage).

$m_{x}$ : The number of living females born per female in each age.

$L_{x}$ : Represents the fraction surviving of females of an initial population of one.

To estimate the stage-specific survival (Ix) and the intrinsic rate of natural increase $\left(r_{m}\right)$, life and age-specific fertility tables were constructed as follows (Southwood, 1978):

$$
\begin{gathered}
\mathbf{R}_{\mathbf{o}}=\sum \mathbf{L}_{\mathbf{x}} \mathbf{m}_{\mathbf{x}} \\
\mathbf{T}=\sum \mathbf{x}\left(\mathbf{L}_{\mathbf{x}} \mathbf{m}_{\mathbf{x}}\right) / \mathbf{R}_{\mathbf{0}} \\
\mathbf{r}_{\mathbf{m}}=\mathbf{I n}\left(\mathbf{R}_{\mathbf{0}}\right) / \mathbf{T}
\end{gathered}
$$

Sex ratio of $C$. genidiella (as males: females) was considered according to Bhadauriya et al. (2011)

\section{RESULTS AND DISCUSSION}

\section{Population density of Cryptoblabes gnidiella in} mango orchards:

To follow up the changes in the population of $C$. gnidiella infesting mango inflorescences, mean numbers of immature stages (larvae and pupae)/ inflorescence were weekly counted during 2016 and 2017 years in mango orchards. The obtained data are graphically illustrated in Figure (1). During the period of study this pest was recorded only at the height of $2.5 \pm 0.5$ meters and was not at the height of $5.5 \pm 0.5$ meters from the ground.

In the first year, during the period lasted from the $1^{\text {st }}$ of March till the $18^{\text {th }}$ of October, the population of $C$. gnidiella had three peaks of abundance. The first peak was recorded on the $18^{\text {th }}$ of April, the second on the $13^{\text {th }}$ of June (the highest) and the third one on the $15^{\text {th }}$ of August. These peaks represented by $9.1,15.9$ and 11 individuals/ inflorescences (Figure, 1).

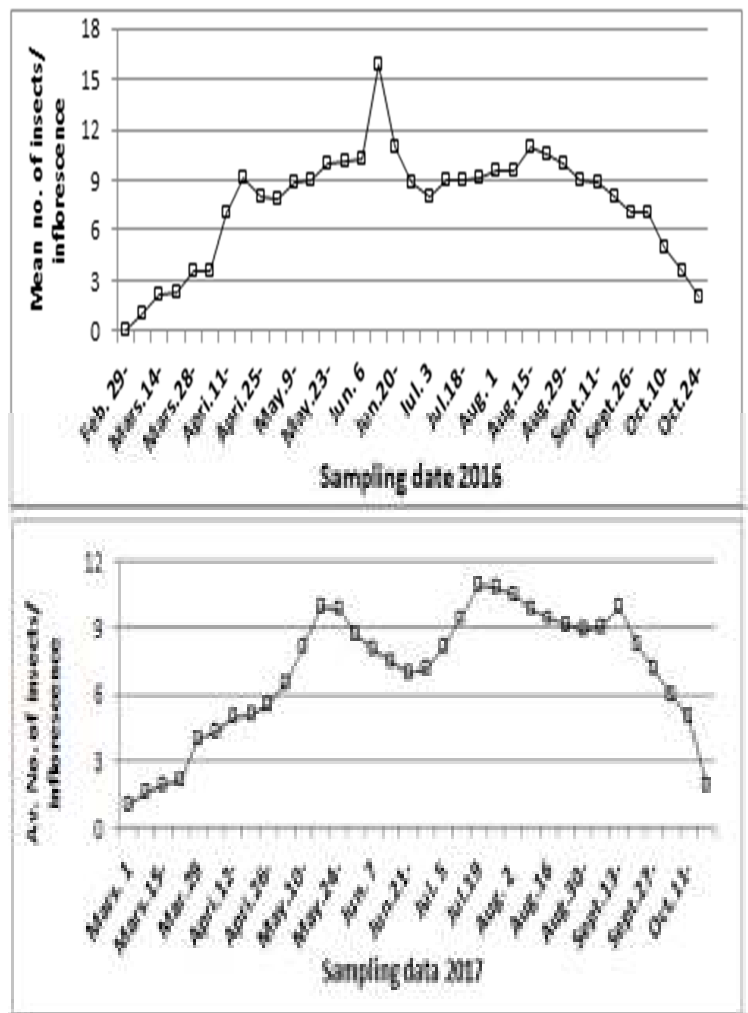

Figure 1. Population density of $C$. gnidiella larval and pupal stages infesting mango inflorescences at Shirben district during 2016 and 2017 years.

In the second year, changes of $C$. gnidiella population showed that the same trend to those of the first year. The honeydew moth population exhibited three peaks of seasonal abundance. The peaks occurred on the $17^{\text {th }}$ of 
May, $19^{\text {th }}$ of July and $13^{\text {th }}$ of September, which represented by 10, 11 and 10 individuals / inflorescence (Figure, 1).

2. Seasonal activity of the natural enemies associated with the $C$. gnidiella:

The obtained data during the two seasons of study revealed that the anthocorid predator, Orius sp. was mainly associated with $C$. gnidiella individuals. In addition, an endo-parasitoid species, which was firstly observed on $C$. gnidiella larvae, namely, Tachina larvarum (Order: Diptera, Family: Tachinidae).

1. The anthocorid predator, Orius sp.:

As shown in Figure (2), Orius sp. started to visit mango inflorescences in the first season, at the first week of March 2016. It exhibited three peaks of seasonal abundance. The first peak (1.6 individuals / inflorescence) was recorded on the first week of May, the second peak was occurred on the first week of July (4.2 individuals / inflorescence) whereas, last one was shown on the second week of September (3.0 individuals / inflorescence).

During the second season (2017), changes of Orius sp. population showed that similar trend to those of the first year. However, Orius sp. population exhibited three peaks of seasonal abundance. The first peak was recorded on the $10^{\text {th }}$ of May, the second on the $12^{\text {th }}$ of July (the highest) and the third on the $27^{\text {th }}$ of September. These peaks represented by 3.0, 5.3 and 2.4 individuals / inflorescence (Figure, 2).

From the statistical point of view, the total number of collected predator (Orius sp.) showed high significantly positive correlation with the average population density of the prey in the first and second years. The correlation coefficient values were $\left(0.51^{* *}\right.$ and $\left.0.63^{* *}\right)$ in the first and the second years (Table, 1$)$. The simple regression for the effect of prey density on Orius sp. population revealed that a highly significant positive effect during the two seasons $(b=0.14$ and 0.25$)$. This means that, each increase of the honey dew moth population by one larva/ inflorescence increased the population of Orius sp. by 0.14 and 0.25 individuals/ inflorescence during the first and second seasons (Table, 1).

\section{The endo-parasitoid, Tachina larvarum:}

The obtained data summarized in Figure (2) revealed that, the population of $T$. larvarum exhibited four peaks of abundance. The first peak was recorded on the $25^{\text {th }}$ of April, the second on the $13^{\text {th }}$ of June, the third on the $15^{\text {th }}$ of August (the highest) and the fourth one on the $3^{\text {rd }}$ of October (Figure, 2). These peaks represented by 1.2, 1.7, 2.3 and 2.0 individuals / inflorescence (Figure, 2).

As shown in Figure (2), there was a visual synchronization between $T$. larvarum and C. gnidiella populations during the first season; whereas, changes of the parasitoid population approximately coincided with those of its host population.

During the second season, changes of T. larvarum population showed similar trend to those of the first year, where T. larvarum population exhibited four peaks of seasonal abundance. The first peak was recorded on the $3^{\text {rd }}$ of May, the second on the $21^{\text {th }}$ of June, the third on the $19^{\text {th }}$ of July (the highest) and the fourth one on the $20^{\text {th }}$ of September (Figure, 2). These peaks represented by 1.2, 2.2, 2.9 and 2.5 individuals / inflorescence (Figure, 2).
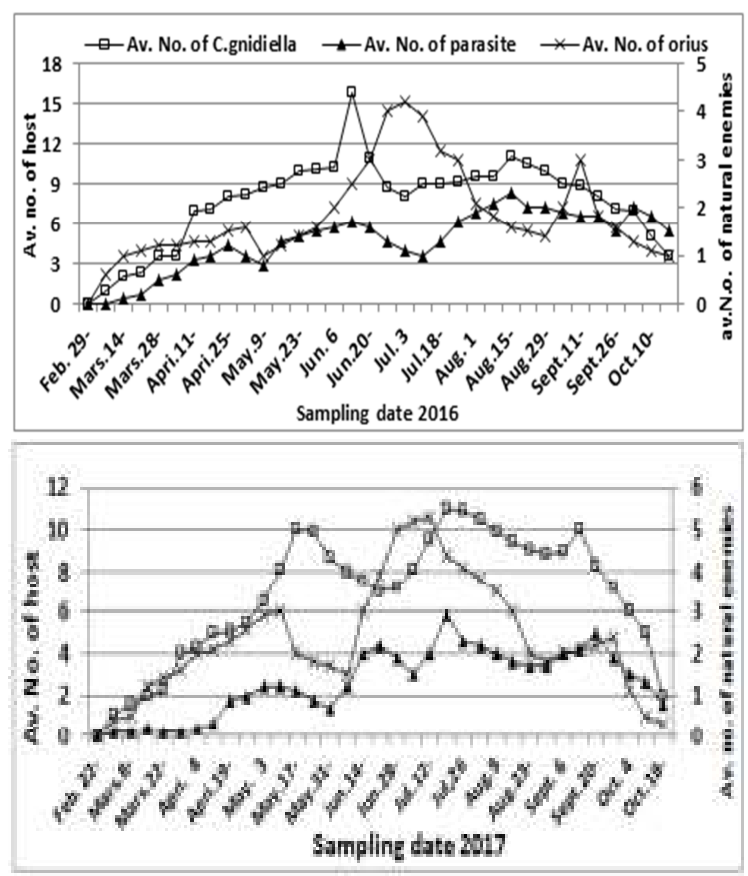

Figure 2. Seasonal activity of the predator, Oruis sp. and the endoparasitoid Tachina larvarum in response to the density of $C$. gnidiella population on mango orchard at Shirben district during 2016 and 2017 years.

Statistical analysis indicated that there was significantly positive correlation between populations of $C$. gnidiella and its parasitoid during the first $\left(\mathrm{r}=0.65^{* *}\right)$ and second $\left(\mathrm{r}=0.79^{* *}\right)$ seasons. On another hand, the simple regression values (b) revealed direct relationship between populations of both the host (Larvae of $C$. gnidiella) and the parasitoid where, each increase of $C$. gnidiella population by one larva/ inflorescence increased the population of $T$. larvarum by 0.12 and 0.22 larvae/ inflorescence during the first and second seasons. Also, statistical analysis showed that C. gnidiella larval population affected parasitoid population by 0.42 and 0.62 (as $\mathrm{R}^{2}$-values) during the first and second seasons (Table, 1).

Table 1. Simple correlation and regression between the host, Cryptoblabes gnidiella and its natural enemies (Orius sp. and Tachina larvarum populations in mango orchards at Shirben district during 2016 and 2017.

\begin{tabular}{lccccc}
\hline \multirow{2}{*}{ Natural enemies } & \multirow{2}{*}{ Year } & \multicolumn{4}{c}{ Correlation and simple regression } \\
\cline { 3 - 6 } & & $\mathbf{R}$ & $\mathbf{b}$ & $\mathbf{P}$ & $\mathbf{R}^{2}$ \\
\hline \multirow{2}{*}{ Orius sp. } & 2016 & 0.51 & 0.14 & 0.0017 & 0.27 \\
\multirow{2}{*}{ Tachina larvarum } & 2017 & 0.63 & 0.25 & 0.0000 & 0.40 \\
\hline & 2016 & 0.65 & 0.12 & 0.0004 & 0.42 \\
& 2017 & 0.79 & 0.21 & 0.0000 & 0.62 \\
\hline
\end{tabular}

The monthly means of parasitism percentage caused by the parasitoid, $T$. larvarum on $C$. gnidiella individuals was estimated and illustrated in Figure (3) for the first and second seasons. The highest activity of T. larvarum was recorded during September, represented by 17.5 and $19.9 \%$, while, the lowest one was recorded during March (8.3 and $6.0 \%$ ) in 2016 and 2017, respectively. The percentage of parasitism all over the season averaged $13.2 \pm 3.2$ and $14.3 \pm 5.01 \%$ during 2016 and 2017 , respectively. 


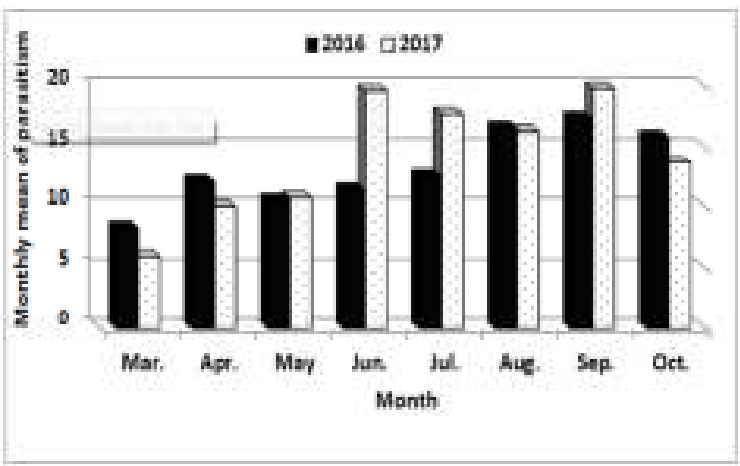

Figure 3. Monthly means of parasitism caused by endoparasitoid, $T$. larvarum on $C$. gnidiella larvae infesting mango inflorescence during 2016 and 2017 seasons.

3. Life and fertility tables for Cryptoblabes gnidiella reared on mango inflorescences:

1. Life table:

Life table analysis were conducted for $C$. gnidiella reared on mango inflorescences based on an initial cohort of 150 eggs under laboratory conditions of $26 \pm 3.5^{\circ} \mathrm{C}$ and $66 \pm 5.5$ R.H.\%. The age-specific survival tables for HM reared under previously mentioned laboratory conditions represented in Table (2).

Data in Table (2) indicate that the egg stage lasted 4.1 \pm 1.8 days. The $1^{\text {st }}, 2^{\text {nd }}, 3^{\text {rd }}, 4^{\text {th }}$ and $5^{\text {th }}$ larval instars durated $2.7 \pm 0.5,2.3 \pm 0.5,3.3 \pm 0.8,3.7 \pm 0.5$ and $2.5 \pm 0.5$ days, respectively. The developmental period of the pupal stage lasted $10.7 \pm 0.9$ days.

The egg stage and the $1^{\text {st }}$ instar larval mortalities $\left(\mathrm{q}_{\mathrm{x}}\right)$ were the highest among all stages and instars. They were 0.187 and 0.156 , respectively. The total developmental duration lasted 29.5 days (Table, 2).

Generally, age-specific survival of HM cleared that eggs and first instar larvae appear to be the key stage mortalities.

Table 2. Life tables of Cryptoblabes gnidiella reared on mango inflorescences under laboratory conditions $\left(26 \pm 3.5^{\circ} \mathrm{C}\right.$ and $66 \pm 5.5$ R.H.\%).

\begin{tabular}{lcccc}
\hline Stage & $\mathbf{X}$ & $\mathbf{I}_{\mathbf{X}}$ & $\mathbf{d}_{\mathbf{X}}$ & $\mathbf{Q}_{\mathbf{X}}$ \\
\hline Egg stage & $4.1 \pm 1.8$ & 150 & 28 & 0.187 \\
\hline Larval stage: & & & & \\
$1^{\text {st }}$ instar & $2.7 \pm 0.5$ & 122 & 19 & 0.156 \\
$2^{\text {nd }}$ instar & $2.3 \pm 0.5$ & 103 & 9 & 0.087 \\
$3^{\text {rd }}$ instar & $3.3 \pm 0.8$ & 94 & 5 & 0.053 \\
$4^{\text {th }}$ instar & $3.7 \pm 0.5$ & 89 & 4 & 0.045 \\
$5^{\text {th }}$ instar & $2.5 \pm 0.5$ & 85 & 4 & 0.047 \\
\hline Pupal stage & $10.7 \pm 0.9$ & 79 & 3 & 0.038 \\
Total immature stage & $29.5 \pm 2.3$ & 76 & 2 & 0.026 \\
\hline
\end{tabular}

\section{Age specific fecundity table:}

The age-specific fertility table is represented in Table (3) for $C$. gnidiella reared under laboratory conditions. From Table (3), the net reproductive rate $\left(\mathrm{R}_{\mathrm{o}}\right)$, the intrinsic rate of natural increase $\left(\mathrm{r}_{\mathrm{m}}\right)$ and the generation time (T) of $C$. gnidiella were calculated.

The duration of a generation of HM as shown in Table (3) lasted about 34.15 days on mango inflorescences. The net reproductive rate $\left(\mathrm{R}_{\mathrm{O}}\right)$ was 29.03 females/ female and the calculated value of intrinsic rate of increase $\left(r_{m}\right)$ which expresses the relationship between fecundity, generation time and its survival was 0.04 .
Table 3. Life table parameters as survival $\left(L_{X}\right)$ and fecundity rate $\left(M_{X}\right)$ of $H M$ moths reared on mango inflorescences for one generation under laboratory conditions $\left(26 \pm 3.5^{\circ} \mathrm{C}\right.$ and $66 \pm 5.5$ R.H.\%).

\begin{tabular}{lcccc}
\hline $\mathbf{X}$ & $\mathbf{L}_{\mathbf{X}}$ & $\mathbf{M}_{\mathbf{X}}$ & $\mathbf{L}_{\mathbf{X}} \cdot \mathbf{M}_{\mathbf{X}}$ & $\sum \mathbf{X}\left(\mathbf{L}_{\mathbf{X}} \cdot \mathbf{M}_{\mathbf{X}}\right)$ \\
\hline 29.5 & 0.509 & 0 & 0 & 0 \\
30.5 & 0.509 & 0 & 0 & 0 \\
31.5 & 0.5 .09 & 1.86 & 0.94674 & 29.82231 \\
32.5 & 0.5 .09 & 5.92 & 3.01328 & 97.9316 \\
33.5 & 0.497 & 6.74 & 3.34978 & 112.2176 \\
34.5 & 0.497 & 6.74 & 3.34978 & 115.5674 \\
35.5 & 0.484 & 7.97 & 3.85748 & 136.9405 \\
36.5 & 0.484 & 8.03 & 3.88652 & 141.858 \\
37.5 & 0.459 & 8.03 & 3.68577 & 138.2164 \\
38.5 & 0.459 & 7.77 & 3.54312 & 136.4101 \\
39.5 & 0.382 & 5.77 & 2.20414 & 87.06353 \\
40.5 & 0.254 & 4.68 & 1.18872 & 48.14316 \\
41.5 & 0.254 & 0 & 29.02533 & 1044.171 \\
\hline
\end{tabular}

The calculated parameters were as follow: $R o=29.03, T=35.97$ and $r_{\mathrm{m}}=0.04$

\section{Discussion}

The honeydew moth (HM), C. gnidiella started to appear on mango inflorescences at the beginning of March to the last week of October with the highest occurrence during June-July. The obtained results agree with Ben Yehuda et al. (1991) and Harari et al. (2007); who found that HM population began to appear in early spring and greatly increased from June to October. Similar results were obtained in Portugal by Silva and Mexia (1999); they mentioned that the highest abundant of HM population was recorded from June until late August. Also, Yildirmm and Başpinar (2015) reported that the population of $C$. gnidiella peaked between mid-August and end of September. In the present investigation, $C$. gnidiella population exhibited 2-3 peaks annually. While, in Adana, Mersin and Osmaniye provinces of the Eastern Mediterranean Region $C$. gnidiella population gave 4-5 generations per year (Öztürk and Ulusoy, 2011). The difference between the present results and others may be attributed to the host plant species and/or the different environmental factors.

The obtained data during the two seasons of study revealed that the anthocorid predator, Orius sp. was mainly associated with $C$. gnidiella population. Similar conclusion was obtained by Yildirım and Bașpinar (2015); they recorded that Orius sp. (Hemiptera: Anthocoridae) was among the main predators associated with $C$. gnidiella population in pomegranate orchard. In addition, the endoparasitoid, Tachina larvarum species, was firstly investigated on $C$. gnidiella larvae infesting mango inflorescences. In pomegranate orchard in Aydın Turkey, the parasitoid Pachycrepoideus vindemmiae (Hymenoptera: Pteromalidae) was found to be reared on the pest. While, in the grapevine orchards in Brazil, five species of Hymenoptera were found associated with $C$. gnidiella: Apanteles sp. (Braconidae), Perilampidae, Pimpla croceiventris (Cresson) (Ichneumonidae), Venturia sp. (Ichneumonidae) and Macrocentrus sp. (Braconidae). Venturia sp. was the most abundant parasitoid. (Bisotto-deOliveira et al. 2007). These different may attributed to the host plant or the climatic factors.

Generally, it could be concluded that the natural enemies, especially the endoparasitoid, $T$. larvarum have played a considerable role in eminently successful biological control projects directed against HM populations. They have some of the important attributes of effective natural enemies \{i.e. number of generation for the parasitoid is considerably more than the host, usually capable of inflicting high mortality in host population, in addition the anthocorid predator, Orius sp. have an excellent good correlation with the prey\}. Therefore, $T$. 
larvarum and Orius sp. proved to be good biological control agents against HM on mango orchards.

Data obtained under laboratory condition cleared that the mean duration period of the different developmental stages of $C$. gnidiella (eggs, larvae and pupae) was $4.1 \pm 1.8, \quad 14.4 \pm 0.6$ and $10.7 \pm 0.9$ days, respectively. These results agree with those obtained by Bhadauriya et al. (2011); they found that the mean incubation period was 3 days, larval period lasted between 8.80-15.40 days; while, the pupal period was 4.40 to 11.00 days. In the present study, mortality of eggs and first instars' larvae proved to be key stage mortalities. Also, Bhadauriya et al. (2011) reported that hatchability percentage was $65.03 \%$.

The net reproductive rate and generation time of $C$. gnidiella reared on mango inflorescences were 29.03 females/female and 35.97 days. According to Wysoki et al. (1993), the average fecundity of $C$. gnidiella reared on grape was 105 eggs /female; while, when the pest reared on hybrid sorghum, female laid an average of 31.0 egg (Bhadauriya et al., 2011).

\section{REFERENCES}

Abd El-Kareim, A.I.; S.A. Moustafa; L.M. Shanab and N.M. Ghanim (2008). Evaluation the role of some parasitoids in biological control of the pink and spiny bollworms in cotton fields. J. Agric. Sci. Mansoura Univ., 33(9): 6811- 6821.

Bagnoli B. and A. Lucchi (2001). Bionomics of Cryptoblabes gnidiella (Milliere) (Pyralidae, Phycitinae) in Tuscan vineyards. IOBC WPRS Bulletin, 24(7): 79-83.

Ben Yehuda, S.; M. Wysoki, and D. Rosen (1991). Phenology of the honeydew moth, Cryptoblabes gnidiella Milliere (Lepidoptera: Pyralidae), on avocado in Israel. Israel Journal of Entomology, XXV-XXVI: 149-160.

Bhadauriya, A.P.S.; A.K.S. Chauhan and B.S. Chandel (2011). Studies on the life cycle of Cryptoblabes gnidiella Miller (Lepidoptera: Pyralidae) on hybrid sorghum. Indian Journal of Entomology, 73(2): 113-115.

Bisotto-de-oliveira, R.; L.R. Redaelli; J.S. Ana and C.M. Botton (2007). Occurrence of Cryptoblabes gnidiella Millière (Lepidoptera: Pyralidae) Associated with grape phenology in Bento Gonçalves, RS. Neotropical Entomology, 36(4): 555-559.

Bugg R.L. and L.T. Wilson (1989). Ammi visnaga (L.) Lamarck (Apiaceae): associated beneficial insects and implications for biological control, with emphasis on the Bell-Pepper agroecosystem. Biol. Agric. \& Horticulture, 6: 241-268.

CoHort Software (2004). Costat. www.cohort.com Montery, California, USA.

Dawidowicz, L. and R. Rozwalka (2016). Honeydew Moth Cryptoblabes gnidiella Millière, 1867 (Lepidoptera: Pyralidae): an adventive species frequently imported with fruit to Poland. Polish Journal of Entomology, 85(2): 181-189.
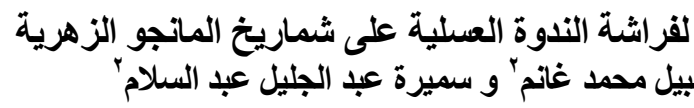

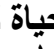
the controlling of pink and spiny bollworms. M.Sc., fac. of Agric., Mansoura Univ., 136 pp.

Harari, A.R.; T. Zahavi; D. Gordon; L. Anshelevich; M. Harel; S. Ovadia and E. Dunkelblum (2007). Pest management programmes in vineyards using male mating disruption. Pest Manag. Sci., 63: 769-775.

Hashem, A.G.; A.W. Tadros and M.A. Abo-Sheasha (1997). Monitoring the honeydew moth, Cryptoblabes gnidiella Mill in citrus, mango and grapevine orchards (Lepidoptera: Pyralidae). Annals of Agricultural Science (Cairo), 42(1): 335-343.

Hashim, S.M.; R.M. Abd El-Moaty and A.W. Tadros (2017). Alternative non-conventional and environmentally safe horticultural, mechanical and local treatments to control Cryptoblabes gnidiella Millière (Lepidoptera: Pyralidae) in pomegranate orchards in the Northwestern Region of Egypt. J. Plant Prot. and Path., Mansoura Univ., 8(10): $511-515$

Mansour, E.S. (2004). Effectiveness of Trichogramma evanescens Westwood, bacterial insecticide and their combination on the cotton bollworms in comparsion with chemical insecticides. Egypt. J. Biol. Pest Control, 14(2): 339-343.

Öztürk N. and M.R. Ulusoy (2011). The adult population dynamics of the Honeydew Moth, Cryptoblabes gnidiella Mill., 1867 (Lepidoptera: Pyralidae) in citrus orchards in the Eastern Mediterranean Region (in Turkish). Bitki Koruma Bülteni, 51(1): 17-32.

Öztürk, N. and M.R. Ulusoy (2012). Determination of adult population dynamics and generation number of Honeydew moth [Cryptoblabes gnidiella Milliere., 1867 (Lepidoptera: Pyralidae)] in pomegranate orchards in the Eastern Mediterranean Region. Türk. entomol. derg., 36 (1): 101-112.

Silva, E.B. and Y.A. Mexia (1999). The pest complex Cryptoblabes gnidiella (Milliére) (Lepidoptera, Pyralidae) and Planococcus citri (Risso) (Homoptera: Pseudococcidae) on sweet orange groves (Citrus sinensis (L.) Osbeck) in Portugal: Interspecific association. Bol. San. Veg. Plagas, 25: 89-98.

Southwood, T.R.E. (1978). Ecological methods. Great Britain, Univ. Printing House, Cambridge, pp. 524.

Wysoki, M.; B.S. Yehuda and D. Rosen (1993). Reproductive behavior of the honeydew moth, Cryptoblabes gnidiella. Invertebrate Reproduction and Development, 24(3): 217-224.

Yildirım, E.M. and H. Başpinar (2015). The population fluctuations of carob moth, Apomyelois ceratoniae (Zell.) (Lepidoptera: Pyralidae) and honeydew moth Cryptoblabes gnidiella Mill. (Lepidoptera: Pyralidae), and investigaton on their damage and natural enemies on pomegranate in West Aegean Region of Turkey. Journal of International Scientific Publications 3: 186192.

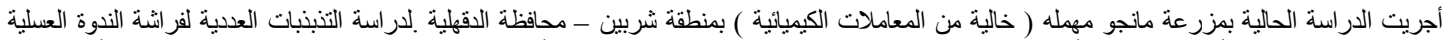

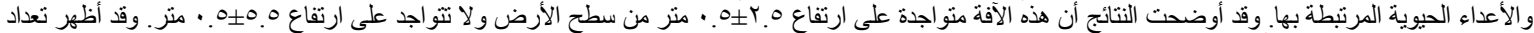

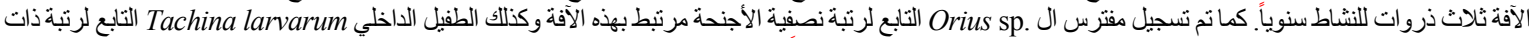

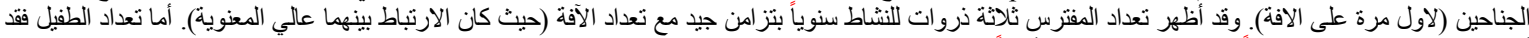

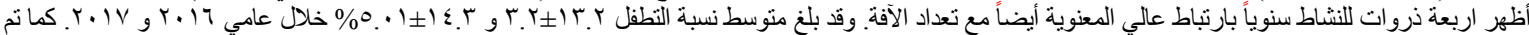

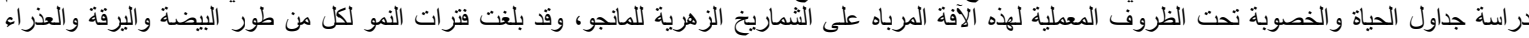

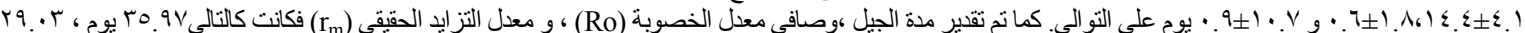
اناث/أنثى ، ع •. • أنثى/أنثى/ جيل.
}

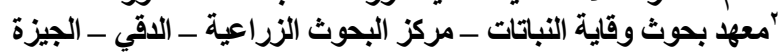

